\title{
Co-deposition of $\mathrm{CuO}$ and $\mathrm{Mn1}$ 1.5Co1.504 powders on Crofer22APU by electrophoretic method: Structural, compositional modifications and corrosion properties
}

\author{
Molin, S.; Sabato, A. G.; Javed, H.; Cempura, G.; Boccaccini, A. R.; Smeacetto, F.
}

Published in:

Materials Letters

Link to article, DOI:

10.1016/j.matlet.2018.02.037

Publication date:

2018

Document Version

Peer reviewed version

Link back to DTU Orbit

Citation (APA):

Molin, S., Sabato, A. G., Javed, H., Cempura, G., Boccaccini, A. R., \& Smeacetto, F. (2018). Co-deposition of $\mathrm{CuO}$ and $\mathrm{Mn}_{15} \mathrm{Co}_{15} \mathrm{O}_{4}$ powders on Crofer22APU by electrophoretic method: Structural, compositional modifications and cortosion properties. Materials Letters, 218, 329-333.

https://doi.org/10.1016/j.matlet.2018.02.037

\section{General rights}

Copyright and moral rights for the publications made accessible in the public portal are retained by the authors and/or other copyright owners and it is a condition of accessing publications that users recognise and abide by the legal requirements associated with these rights.

- Users may download and print one copy of any publication from the public portal for the purpose of private study or research.

- You may not further distribute the material or use it for any profit-making activity or commercial gain

- You may freely distribute the URL identifying the publication in the public portal 


\section{Accepted Manuscript}

Co-deposition of $\mathrm{CuO}$ and $\mathrm{Mn}_{1.5} \mathrm{Co}_{1.5} \mathrm{O}_{4}$ powders on Crofer22APU by electrophoretic method: structural, compositional modifications and corrosion properties

S. Molin, A.G. Sabato, H. Javed, G. Cempura, A.R. Boccaccini, F. Smeacetto

PII: S0167-577X(18)30243-X

DOI: https://doi.org/10.1016/j.matlet.2018.02.037

Reference: MLBLUE 23863

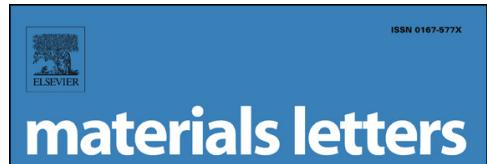

To appear in:

Materials Letters

Received Date: 30 November 2017

Revised Date:

7 February 2018

Accepted Date:

10 February 2018

Please cite this article as: S. Molin, A.G. Sabato, H. Javed, G. Cempura, A.R. Boccaccini, F. Smeacetto, Codeposition of $\mathrm{CuO}$ and $\mathrm{Mn}_{1.5} \mathrm{Co}_{1.5} \mathrm{O}_{4}$ powders on Crofer22APU by electrophoretic method: structural, compositional modifications and corrosion properties, Materials Letters (2018), doi: https://doi.org/10.1016/j.matlet.2018.02.037

This is a PDF file of an unedited manuscript that has been accepted for publication. As a service to our customers we are providing this early version of the manuscript. The manuscript will undergo copyediting, typesetting, and review of the resulting proof before it is published in its final form. Please note that during the production process errors may be discovered which could affect the content, and all legal disclaimers that apply to the journal pertain. 


\title{
Co-deposition of $\mathrm{CuO}$ and $\mathrm{Mn}_{1.5} \mathrm{Co}_{1.5} \mathrm{O}_{4}$ powders on Crofer22APU by electrophoretic method:
}

structural, compositional modifications and corrosion properties

\author{
S. Molin ${ }^{1}$, A.G. Sabato ${ }^{2}$, H. Javed ${ }^{2}$, G. Cempura ${ }^{3}$, A.R. Boccaccini ${ }^{4}$, F. Smeacetto ${ }^{2 *}$ \\ ${ }^{1}$ Department of Energy Conversion and Storage, Technical University of Denmark, \\ Risø Campus, 4000 Roskilde, Denmark \\ ${ }^{2}$ Department of Applied Science and Technology, DISAT, Politecnico di Torino, \\ Corso Duca degli Abruzzi 24, 10129 Torino, Italy \\ ${ }^{3}$ AGH University of Science and Technology, \\ al. Mickiewicza 30, 30-059 Krakow, Poland \\ ${ }^{4}$ Department of Materials Science and Engineering, University of Erlangen-Nuremberg, \\ Cauerstr. 6, 91058 Erlangen, Germany
}

* corresponding author, e-mail federico.smeacetto@polito.it, phone +390110904756

\begin{abstract}
Co-deposition of $\mathrm{CuO}$ and $\mathrm{Mn}_{1.5} \mathrm{Co}_{1.5} \mathrm{O}_{4}$ by single step electrophoretic deposition is used to produce $\sim 15 \mu \mathrm{m}$ coatings on Crofer22APU steel, which finds use as interconnect for high temperature solid oxide cells. Sintering of the green coatings in reducing and then oxidizing conditions led to formation of a mixed $(\mathrm{Cu}, \mathrm{Mn}, \mathrm{Co})_{3} \mathrm{O}_{4}$ spinel. By the incorporation of $\mathrm{Cu}$, the density of the coatings improved. Scanning and transmission electron microscopy observations, supplemented with energy dispersive spectroscopy, confirmed dissolution of $\mathrm{Cu}$ in the spinel phase. For the un-doped $\mathrm{Mn}_{1.5} \mathrm{Co}_{1.5} \mathrm{O}_{4}$ both the tetragonal and cubic phases are detected at room temperature by $\mathrm{x}$-ray diffractometry, whereas the addition of $\mathrm{Cu}$ seems to stabilize the cubic phase. Initial ( 1000 hours) high temperature corrosion evaluation at $800^{\circ} \mathrm{C}$ in air showed promising properties of the mixed spinel coating.
\end{abstract}

Keywords: ceramics; corrosion; deposition; sintering; 


\section{Introduction}

Mn-Co spinels have been suggested as the best candidates for protective materials for steel interconnects of Solid Oxide Cells [1,2]. They possess high electrical conductivity and thermal expansion coefficient (TEC) compatibility with metallic interconnect substrates. The doping of manganese cobaltite spinel with transition metals such as $\mathrm{Fe}$ and $\mathrm{Cu}$ has been previously evaluated [3]. $\mathrm{Cu}$ is an attractive dopant for increasing both the sinterability, the electrical conductivity of the spinel as well as the density of the obtained coatings with regard to the prevention of chromium volatilization $[4,5]$. The $\mathrm{Cu} / \mathrm{Fe}$ doped spinel powders are typically prepared "ex-situ" (by soft chemistry or mechanochemical synthesis) in a separate process before the deposition, thus increasing the processing time and cost [6-8].

The novelty reported in this paper is the ability of using EPD to simultaneously co-deposit the MnCo spinel and the dopant $(\mathrm{Cu})$ by adding a controlled amount of the second phase $(\mathrm{CuO})$ to the suspension, thus in only one deposition step. Though the EPD has been used for preparation of protective coating in a few studies [9-13], co-deposition approach proposed in this work is a new and an interesting route.

\section{Experimental}

Crofer22APU (0.3 mm thick, VDM Metals, Germany) was used as substrate for EPD. Commercial $\mathrm{Mn}_{1.5} \mathrm{Co}_{1.5} \mathrm{O}_{4}$ powder (mean particle size of $0.36 \mu \mathrm{m}$ ), purchased from American Elements (USA) was mixed with $\mathrm{CuO}$ (Alfa Aesar) obtaining suspensions with different $\mathrm{CuO}$ contents. In particular, 0 wt. $\%$. 5 wt. $\%$ and 10 wt. $\%$ of $\mathrm{CuO}$ were used, maintaining constant the solid content of the ethanol and deionized water based $\left(60 / 40\right.$ vol. of EtOH/ $\left.\mathrm{H}_{2} \mathrm{O}\right)$ suspensions $\left(37.5 \mathrm{~g} \mathrm{~L}^{-1}\right)$. The Crofer22APU substrates were cleaned in acetone prior to the electrophoretic deposition. A Crofer22APU substrate was used as the counter electrode in the EPD cell. The distance between both electrodes was $10 \mathrm{~mm}$ and a constant voltage of $50 \mathrm{~V}$ was applied for 20 secs. The samples were dried at room temperature for $24 \mathrm{~h}$ in air. 
Un-doped and $\mathrm{Cu}$-doped $\mathrm{Mn}_{1.5} \mathrm{Co}_{1.5} \mathrm{O}_{4}$ coated Crofer22APU samples (labeled as $5 \mathrm{CuMCO}$ and $10 \mathrm{CuMCO}$ respectively) were processed with a two-step sintering procedure (first $900{ }^{\circ} \mathrm{C}$ for $2 \mathrm{hrs}$ in a $\mathrm{Ar}-4 \% \mathrm{H}_{2}$ and subsequently at $900{ }^{\circ} \mathrm{C}$ for $2 \mathrm{hrs}$ in air). For the x-ray diffractometry (XRD) studies, Bruker D8 Advance with CuKa radiation was used. For in-situ high temperature XRD measurements, an MRI attachment with Pt-Rh heating strip was used. Corrosion exposures of the samples were performed for 1000 hours in static air at $800^{\circ} \mathrm{C}$ in a chamber furnace. For each type of coated samples, 5 individual samples were used for reproducibility and an average weight gain values are presented. Area specific resistance (ASR) measurements have been performed according to the procedure presented in [14]. Metallographic cross sections of the coated alloys were prepared by embedding samples in epoxy and polishing to $1 \mu \mathrm{m}$ finish (using Struers consumables). SEM analyses of sample surfaces and cross-sections were performed by using Hitachi TM3000 with EDS from Bruker (Quantax70 SDD). The sample obtained from the suspension containing the $5 \mathrm{wt} \%$ of $\mathrm{CuO}$ was submitted to STEM/EDS/SAED investigations. These analyses were performed with a FEI Tecnai G2 and a Titan Cubed 2 60-300 (STEM EDS) microscopes on a thin lamella prepared by focused ion beam (FIB using Zeiss NEON CrossBeam 40) at the steel/coating interface.

\section{Results and discussion}

Formation of $\mathrm{Cu}$-doped spinel by a co-deposition process using commercial powders can be considered a new and promising route for spinel modification. As earlier works show $[4,5,15]$, TEC and electrical conductivity might be matched to a desired level by doping of the spinel by $\mathrm{Cu}$ and/or Fe, thus tailoring for specific alloy and possible operation temperature.

Figure 1 shows SEM images of the coated alloy surfaces after the reduction (A, B, C) and subsequent re-oxidation step (D, E, F). Small metallic Co particles are observed in all reduced samples with larger $\mathrm{Cu}$ particles clearly distinguishable in the doped samples. After the reoxidation, coating looks uniform and no residual $\mathrm{CuO}$ can be detected. Despite the large amount of 
copper, no cracks were detected on the surface of the $10 \mathrm{CuMnCo}$, as it can be observed in Figure $1 \mathrm{~F}$.

XRD patterns after the reducing heat treatment are shown in Figure 2 A. As expected, the MnCo spinel was decomposed into $\mathrm{MnO}$ and $\mathrm{Co}$, while the $\mathrm{CuO}$ doped spinel decomposed to $\mathrm{MnO}$, Co and $\mathrm{Cu}$ (the intense peaks of $\mathrm{Pt}$ are due to the sample holder). After the re-oxidation step $\left(900^{\circ} \mathrm{C}\right.$ 2hrs), re-formation of the spinel is visible. In the case of the un-doped MCO, both cubic and tetragonal phases are distinguishable, whereas for the $\mathrm{Cu}$-doped, the peaks from the tetragonal phase are less intense. This is confirmed by HT-XRD (Figure $2 \mathrm{C}$ ). At high temperatures $\left(>500^{\circ} \mathrm{C}\right.$ ) only a cubic phase is visible. Upon reaching $500^{\circ} \mathrm{C}$, peak from the tetragonal phase is becoming visible, indicating formation of the new phase below this temperature. This is seen for the un-doped spinel. For the $5 \mathrm{CuMCO}$ spinel, much less of the tetragonal phase forms. This result may indicate that certain parts of the coating do not contain sufficient amounts of copper, allowing domains of the tetragonal phase to remain.

Furthermore, these measurements did not indicate any evidence of the presence of trace amounts of residual $\mathrm{CuO}$ in all coatings. These results provide thus further support for the hypothesis that copper becomes incorporated into the manganese cobaltite spinel lattice, thus stabilising the cubic phase.

The cross sections SEM images of the re-oxidized 5 wt.\% and 10 wt.\% Cu doped MnCo-based coatings, are shown in Figure $3 \mathrm{~A}$ and $\mathrm{B}$. The coatings look dense since few residual pores in the coating appear all to be isolated and not interconnected. Furthermore, the $\mathrm{Cu}$ distribution appears to be uniform and well distributed throughout the MnCo coating.

The obtained coatings were compact and exhibited a good adhesion to the Crofer22APU substrate. The thickness of the $\mathrm{Cu}$ coatings was found to be 13 and 10 microns for the 5CuMCO and 10CuMCO respectively, thus highlighting a higher degree of densification with a higher amount of added $\mathrm{Cu}$. 
The corresponding FIB lamella with relative EDS mapping and SAED analyses are shown in Figure $3 \mathrm{C}$-D. STEM/EDS analysis, presented for the 5CuMCO sample (C) confirms that $\mathrm{Cu}$ is evenly distributed in the coating. The SAED patterns (Figure $3 \mathrm{D}$ ) were collected on two different grains on which $\mathrm{Mn}, \mathrm{Co}$ and $\mathrm{Cu}$ seems to be present together, thus suggesting that $\mathrm{Cu}$ entered the spinel structure. The SAED identification revealed the presence of the $\mathrm{MnCo}_{2} \mathrm{O}_{4}$ cubic phase only.

The high temperature corrosion properties of the modified spinels were verified and compared with the un-doped spinel by weight gain (corrosion kinetics) and area specific resistance (ASR) measurements, presented in Figure $4 \mathrm{~A}$ and B. Comparing the weight gains of the coated alloys, the results are similar with only minor differences found. The addition of $\mathrm{Cu}$ to the spinel does not result in deteriorated corrosion protection capabilities. It is worth noting, that uncoated Crofer22APU has a corrosion rate of $\sim 6 \times 10^{-14} \mathrm{~g}^{2} \mathrm{~cm}^{-4} \mathrm{~s}^{-1}$ in similar conditions [16]. The application of coatings reduces corrosion rate by a factor of $\sim 10$. In the ASR measurement, slightly lower values were found for the $\mathrm{Cu}$-doped spinels, but up to $1000 \mathrm{hrs}$ of test the differences can be considered within the experimental uncertainties. Based on these initial corrosion examinations, it might be concluded that incorporation of $\mathrm{Cu}$ does not lead to deteriorated high temperature corrosion protective properties, and slightly improved the ASR behaviour, as studied for the 1000 hours period.

\section{Conclusions}

$\mathrm{Cu}$-doped manganese cobaltite coated Crofer22APU samples were successfully processed by electrophoretic deposition. Single step co-deposition of the $\mathrm{Mn}_{1.5} \mathrm{Co}_{1.5} \mathrm{O}_{4}$ and $\mathrm{CuO}$ is an effective way for the spinel modification since single phase materials has been obtained. The effect of $\mathrm{Cu}$ doping was reviewed and discussed with respect to structural, compositional changes and sintering behavior. $\mathrm{Cu}$ seems to stabilize the cubic phase of the spinel, decreasing the amount of the tetragonal phase. The addition of $\mathrm{Cu}$ improves the coating density, which should be beneficial for 
blocking $\mathrm{Cr}$ vaporization. Good electrical and corrosion protective properties of the modified manganese cobaltite spinel were shown.

\section{References}

[1] N. Shaigan, W. Qu, D.G. Ivey, W. Chen, A review of recent progress in coatings, surface modifications and alloy developments for solid oxide fuel cell ferritic stainless steel interconnects, J. Power Sources. 195 (2010) 1529-1542.

[2] F. Smeacetto, A. De Miranda, S. Cabanas Polo, S. Molin, D. Boccaccini, M. Salvo, et al., Electrophoretic Deposition of Mn1.5 Co1.5 O4 on Metallic Interconnect and Interaction with Glassceramic Sealant for Solid Oxide Fuel Cells Application, J. Power Sources. 280 (2015) 379-386. doi:10.1016/j.jpowsour.2015.01.120.

[3] M. Bobruk, K. Durczak, J. Dąbek, T. Brylewski, Structure and Electrical Properties of Mn-Cu-O Spinels , Journal of Materials Engineering and Performance 26 (2017)1598-1604. doi.org/10.1007/s11665-017-2588-8

[4] A. Masi, M. Bellusci, S.J. McPhail, F. Padella, P. Reale, J.-E. Hong, et al., The effect of chemical composition on high temperature behaviour of $\mathrm{Fe}$ and $\mathrm{Cu}$ doped Mn-Co spinels, Ceram. Int. 43 (2017) 2829-2835. doi:10.1016/j.ceramint.2016.11.135.

[5] D. Szymczewska, S. Molin, P. Hendriksen, P. Jasiński, Microstructure and Electrical Properties of Fe,Cu Substituted (Co,Mn)3O4 Thin Films, Cryst. 2017, Vol. 7, Page 185.7 (2017) 185. doi:10.3390/CRYST7070185.

[6] T. Brylewski, W. Kucza, A. Adamczyk, A. Kruk, M. Stygar, M. Bobruk, et al., Microstructure and electrical properties of $\mathrm{Mn} 1+\mathrm{xCo} 2-\mathrm{xO} 4(0 \leq \mathrm{x} \leq 1.5)$ spinels synthesized using EDTA-gel processes, Ceram. Int. 40 (2014) 13873-13882. doi:10.1016/j.ceramint.2014.05.106.

[7] A. Masi, M. Bellusci, S.J. McPhail, F. Padella, P. Reale, J.-E. Hong, et al., Cu-Mn-Co oxides as protective materials in SOFC technology: The effect of chemical composition on mechanochemical synthesis, sintering behaviour, thermal expansion and electrical conductivity, J. Eur. Ceram. Soc. 37 
(2017) 661-669. doi:10.1016/j.jeurceramsoc.2016.09.025.

[8] B. Talic, S. Molin, K. Wiik, P.V. Hendriksen, H.L. Lein, Comparison of iron and copper doped manganese cobalt spinel oxides as protective coatings for solid oxide fuel cell interconnects, J. Power Sources. 372 (2017) 145-156. doi:10.1016/j.jpowsour.2017.10.060.

[9] A.R. Boccaccini, I. Zhitomirsky, Application of electrophoretic and electrolytic deposition techniques in ceramics processing, Curr. Opin. Solid State Mater. Sci. 6 (2002) 251-260. doi:10.1016/S13590286(02)00080-3.

[10] M. Mirzaei, A. Simchi, M.A. Faghihi-Sani, A. Yazdanyar, Electrophoretic deposition and sintering of a nanostructured manganese-cobalt spinel coating for solid oxide fuel cell interconnects, Ceram. Int. 42 (2016) 6648-6656. doi:10.1016/j.ceramint.2016.01.012.

[11] H. Abdoli, P. Alizadeh, Electrophoretic deposition of (Mn,Co)3O4 spinel nano powder on SOFC metallic interconnects, Mater. Lett. 80 (2012) 53-55. doi:10.1016/j.matlet.2012.04.072.

[12] H. Zhang, Z. Zhan, X. Liu, Electrophoretic deposition of (Mn,Co)3O4 spinel coating for solid oxide fuel cell interconnects, J. Power Sources. 196 (2011) 8041-8047. doi:10.1016/j.jpowsour.2011.05.053.

[13] Y. Zhang, A. Javed, M. Zhou, S. Liang, P. Xiao, Fabrication of Mn-Co Spinel Coatings on Crofer 22 APU Stainless Steel by Electrophoretic Deposition for Interconnect Applications in Solid Oxide Fuel Cells, Int. J. Appl. Ceram. Technol. 11 (2014) 332-341. doi:10.1111/ijac.12013.

[14] S. Molin, P. Jasinski, L. Mikkelsen, W. Zhang, M. Chen, P.V. Hendriksen, Low temperature processed $\mathrm{MnCo} 2 \mathrm{O} 4$ and $\mathrm{MnCo} 1.8 \mathrm{Fe} 0.2 \mathrm{O} 4$ as effective protective coatings for solid oxide fuel cell interconnects at $750{ }^{\circ} \mathrm{C}$, J. Power Sources. 336 (2016) 408-418. doi:10.1016/j.jpowsour.2016.11.011.

[15] T. Brylewski, A. Kruk, M. Bobruk, A. Adamczyk, J. Partyka, P. Rutkowski, Structure and electrical properties of $\mathrm{Cu}$-doped $\mathrm{Mn}-\mathrm{Co}-\mathrm{O}$ spinel prepared via soft chemistry and its application in intermediate-temperature solid oxide fuel cell interconnects, J. Power Sources. 333 (2016) 145-155. doi:10.1016/j.jpowsour.2016.09.136. 
[15] S. Molin, M. Chen, J.J. Bentzen, P. V. Hendriksen, High Temperature Oxidation of Ferritic Steels for Solid Oxide Electrolysis Stacks, ECS Trans. 50 (2013) 11-20. doi:10.1149/05030.0011ecst.

\section{Captions}

Figure 1. SEM surface images of reduced (top row) and re-oxidized (bottom row) coatings A,D) MCO, B,E) 5CuMCO and C,F) 10CuMCO and re-oxidized coatings.

Figure 2. XRD study of the coated alloys. Spectra of: A) reduced coatings at RT, B) oxidized $\left(800^{\circ} \mathrm{C}\right)$ coatings at RT, C) HT-XRD measured during cooling from $800^{\circ} \mathrm{C}$ to RT.

Figure 3. SEM (A,B) and TEM/SAED (C) cross-sections and elemental maps of A) 5CuMCO, B) 10CuMCO and C) 5CuMCO. D) experimental and superimposed theoretical SAED patterns.

Figure 4. Comparison of (A) cyclic thermogravimetric and (B) area specific resistance measurement $(\mathrm{B})$ of the coated samples. 


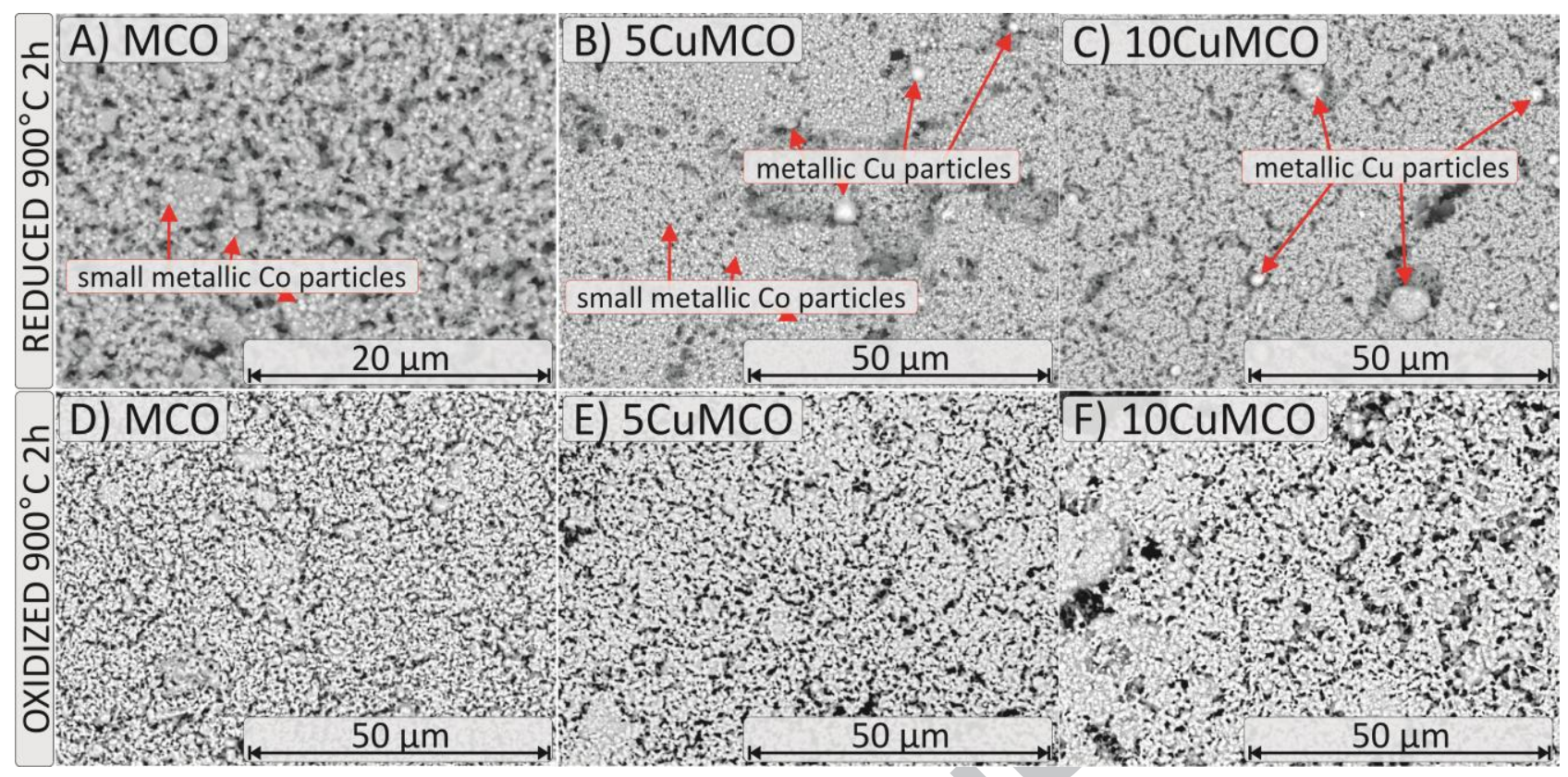


A) REDUCED

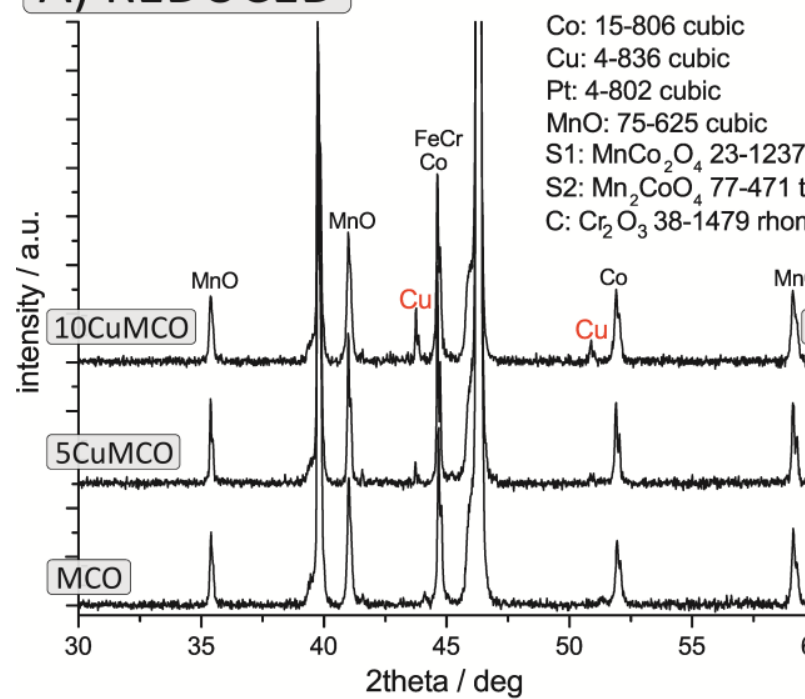

B) OXIDIZED

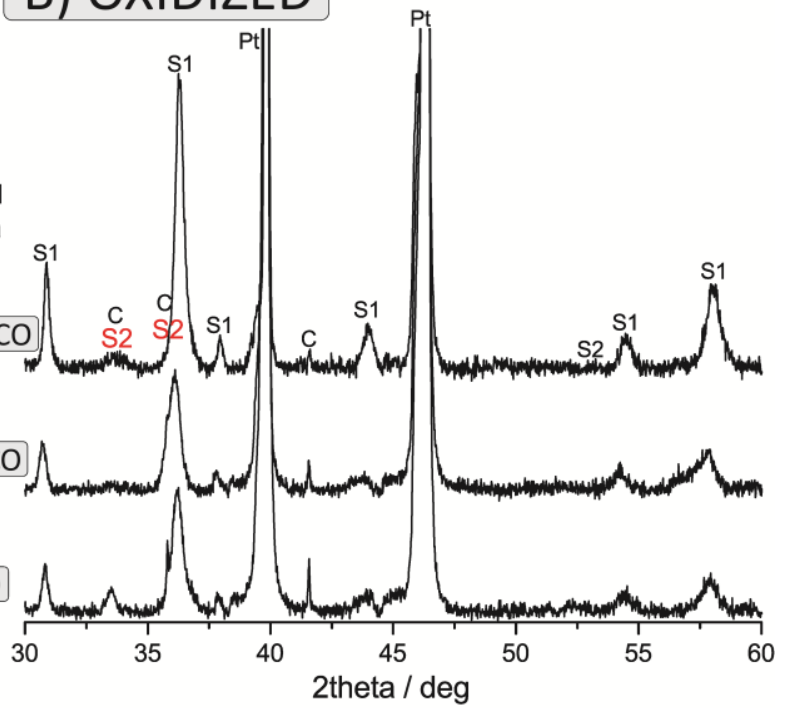

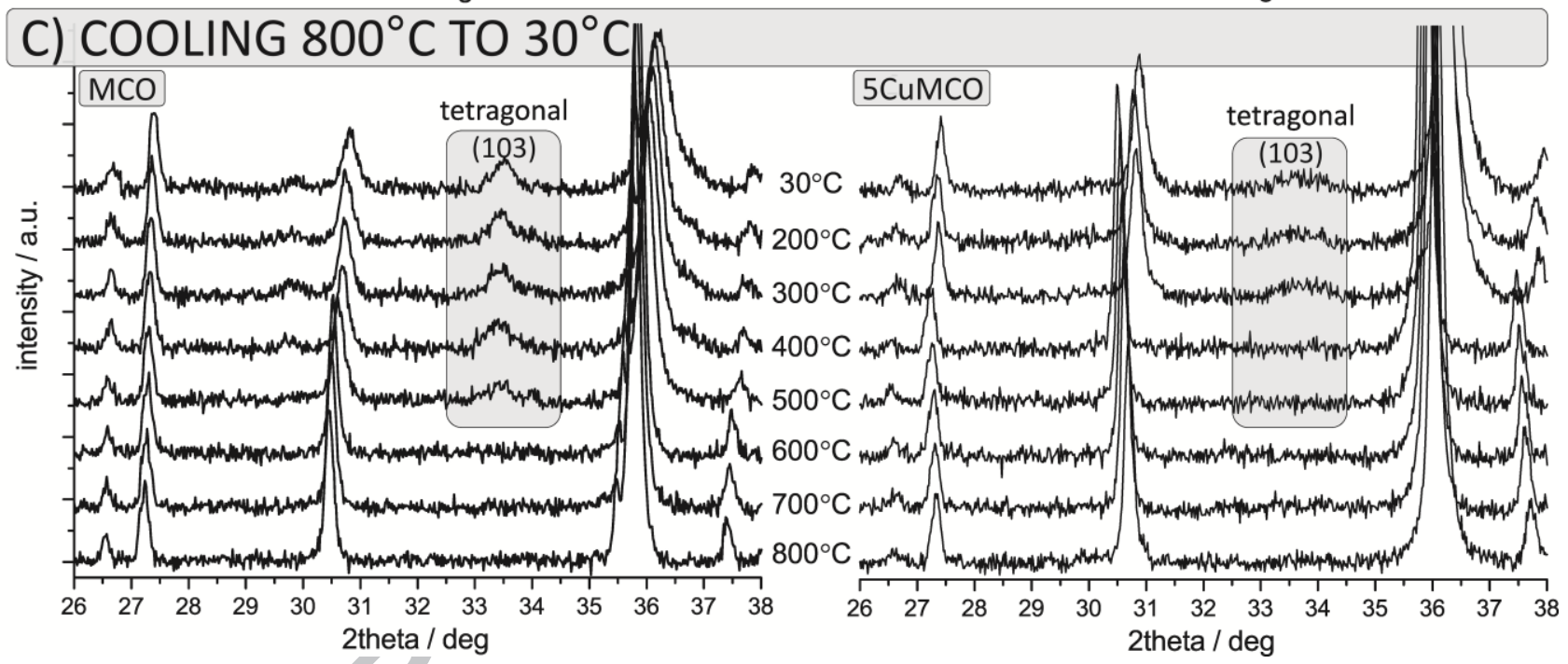




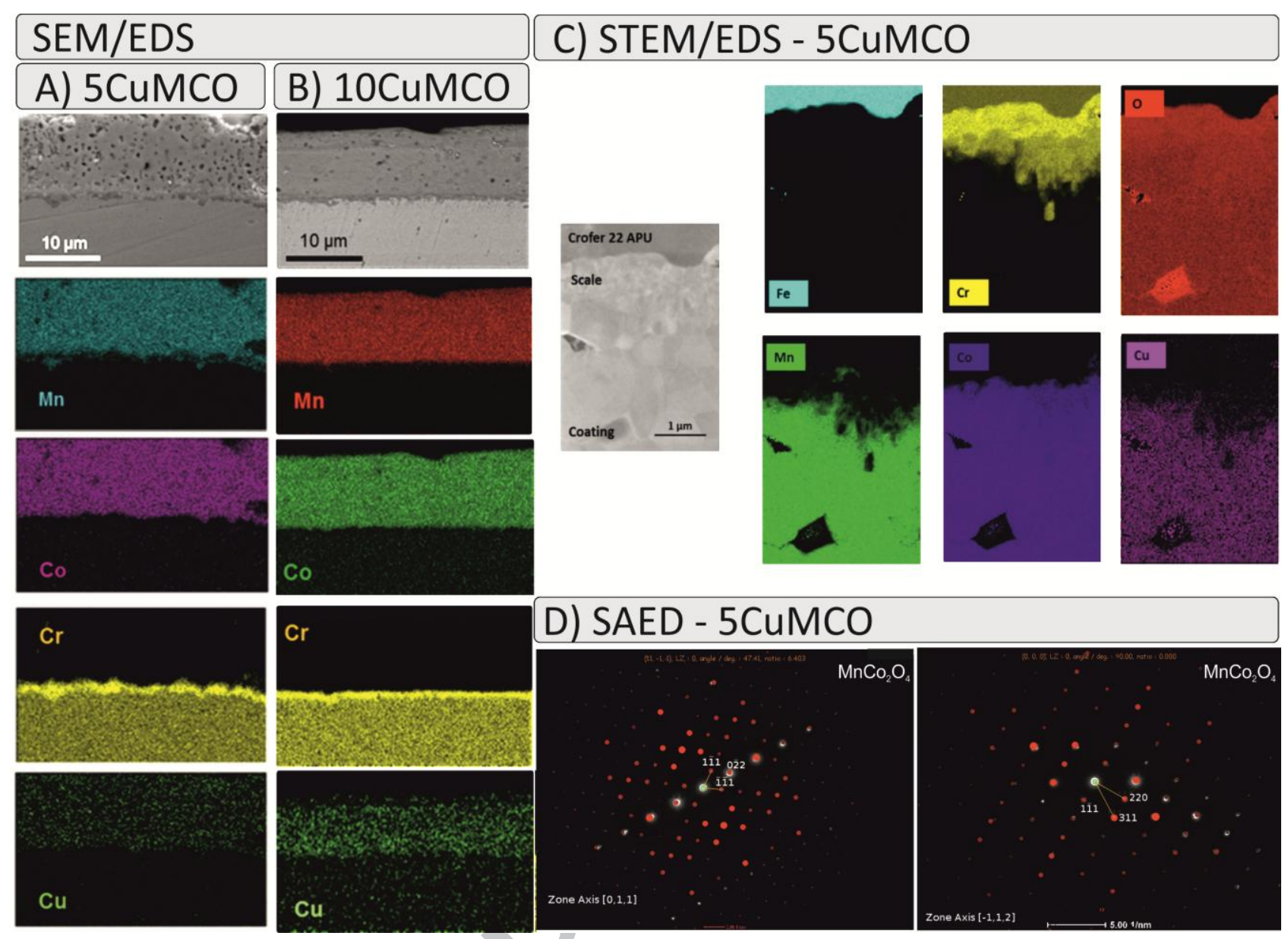




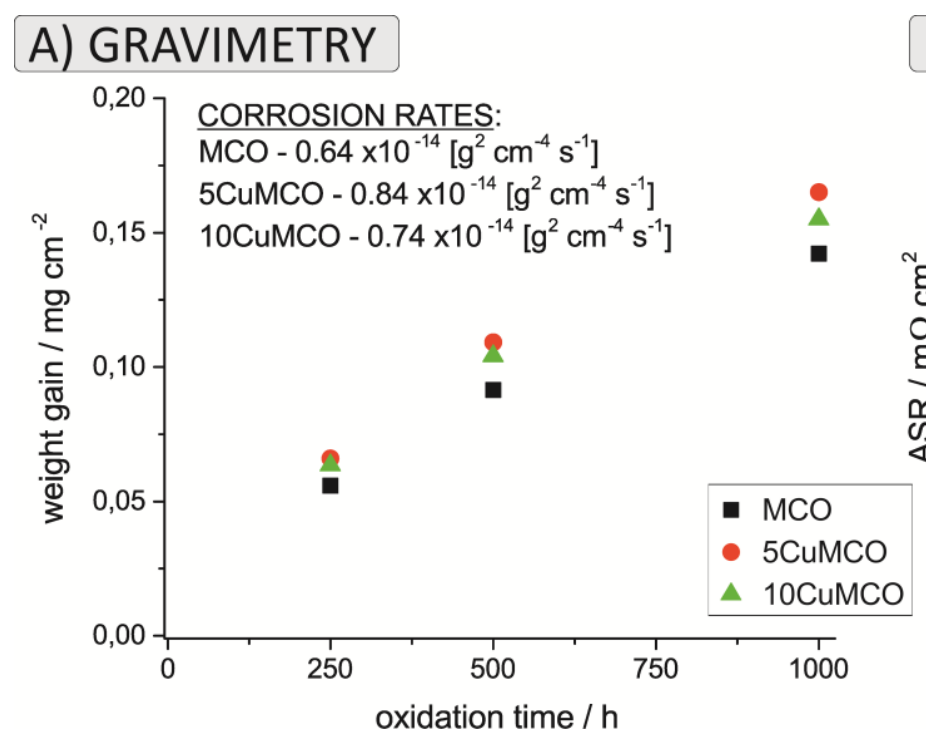

B) ASR

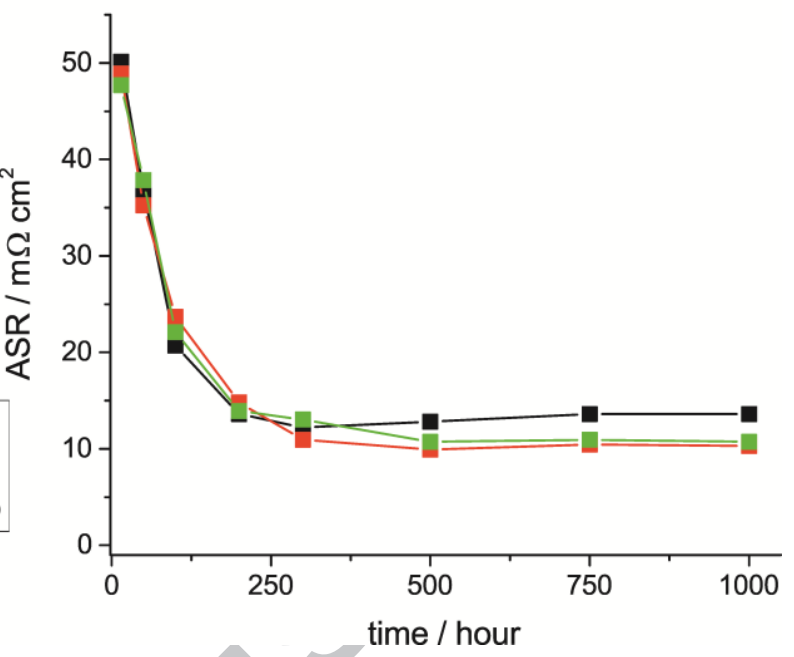


- Co-deposition of $\mathrm{CuO}$ and $\mathrm{Mn}_{1.5} \mathrm{Co}_{1.5} \mathrm{O}_{4}$ by single step electrophoretic deposition

- $\mathrm{Cu}$ stabilized the cubic phase of the MnCo spinel

- $\mathrm{Cu}$ slightly improved the ASR behavior, as studied for the $1000 \mathrm{hrs}$ period 